Dwi Rahmah Inayati, Ati Kusmawati : Penerapan Metode Everyone Is Teacher Here untuk Meningkatkan Hasil Belajar IPS Pada Siswa Kelas V SD Negeri Cempaka Baru 07 Pagi Jakarta

\title{
PENERAPAN METODE EVERYONE IS TEACHER HERE UNTUK MENINGKATKAN HASIL BELAJAR IPS PADA SISWA KELAS V SD NEGERI CEMPAKA BARU 07 PAGI JAKARTA
}

\author{
Dwi Rahmah Inayati ${ }^{1}$, Ati Kusmawati² \\ ${ }^{1}$ Pendidikan Guru Sekolah Dasar, FKIP, Universitas Muhammadiyah Jakarta, \\ email : dwirahmah8316@gmail.com \\ ${ }^{2}$ Pendidikan Guru Sekolah Dasar, FKIP, Universitas Muhammadiyah Jakarta, \\ email : ati2051976@gmail.com
}

\begin{abstract}
This research is motivated by the existence of student learning outcomes in social science subjects Theme 8 Sub theme 3 Material Types of Business and Economic Activities under the KKM, so that the writer is moved to research and propose solutions by applying the Everyone is Teacher Here method. The purpose of this study was to improve social studies learning outcomes in fifth grade students at SDN Cempaka Baru 07 Pagi. The method used is classroom action research. The study was conducted in two cycles with indicators of the success of students' scores in the cognitive domain $\geq 70$, in the affective domain $\geq 2.33$ with the B-category, in the domain of skills category B, mastery learning $\geq 70 \%$ and learning outcomes in cycle II $>$ of cycle I. The results showed the average value of students from 47.42 in the pre cycle increased to 49.36 at meeting 1, increased to 56.77 at meeting 2. At cycle II meeting 1 increased again to 68.55 and meeting 2 to 74,19 . The percentage of pre-cycle study completion $19.35 \%$ increase in cycle I meeting 1 to $25.81 \%$, meeting 2 to $51.61 \%$, cycle II meeting 1 to $77.42 \%$ and meeting 2 to $80.65 \%$. The average value of affective learning outcomes in cycle I was $3.27(B+)$, then increased in cycle II to 3.52 (A). The learning outcomes of the first cycle skill get an average score in category $C$ and increase in cycle II to category B. This shows that the everyone is Teacher Here method can improve the learning outcomes of social studies in class V students of SDN Cempaka Baru 07 Pagi.
\end{abstract}

Keywords: Everyone is Teacher Here Method, Learning Outcomes, and Social Studies Subjects.

\begin{abstract}
ABSTRAK
Penelitian ini dilatarbelakangi adanya hasil belajar siswa pada mata pelajaran IPS Tema 8 Subtema 3 Materi Jenis Usaha dan Kegiatan Ekonomi yang berada di bawah KKM, sehingga penulis tergerak untuk meneliti dan mengajukan solusi dengan menerapkan metode Everyone is Teacher Here. Tujuan penelitian ini adalah untuk meningkatkan hasil belajar IPS pada siswa kelas V SDN Cempaka Baru 07 Pagi. Metode yang digunakan adalah penelitian tindakan kelas. Penelitian dilaksanakan dalam dua siklus
\end{abstract}


dengan indikator keberhasilan nilai siswa pada ranah kognitif $\geq 70$, pada ranah afektif $\geq 2,33$ dengan kategori B-, pada ranah keterampilan kategori $\mathrm{B}$, ketuntasan belajar $\geq$ $70 \%$ dan hasil belajar pada siklus II > dari siklus I. Hasil penelitian menunjukkan nilai rata-rata siswa dari 47,42 pada pra siklus meningkat menjadi 49,36 pada pertemuan 1, meningkat menjadi 56,77 pada pertemuan 2. Pada siklus II pertemuan 1 meningkat lagi menjadi 68,55 dan pertemuan 2 menjadi 74,19. Persentase tuntas belajar pra siklus $19,35 \%$ meningkat di siklus I pertemuan 1 menjadi $25,81 \%$, pertemuan 2 menjadi $51,61 \%$, siklus II pertemuan 1 menjadi 77,42\% dan pertemuan 2 menjadi 80,65\%. Perolehan nilai rata-rata hasil belajar afektif pada siklus I sebesar 3,27 (B+), kemudian meningkat pada siklus II menjadi 3,52 (A). Hasil belajar ranah keterampilan siklus I mendapat nilai rata-rata kategori $\mathrm{C}$ dan meningkat di siklus II menjadi kategori B. Hal ini menunjukkan bahwa metode Everyone is Teacher Here dapat meningkatkan hasil belajar IPS pada siswa kelas V SDN Cempaka Baru 07 Pagi.

Kata Kunci: Metode Everyone is Teacher Here, Hasil Belajar, Mata Pelajaran IPS.

\section{PENDAHULUAN}

Pembelajaran yang terpusat pada guru menyebabkan siswa merasa jenuh karena tidak terlibat aktif dalam pembelajaran. Permasalahan mengenai pembelajaran IPS ini terjadi di SDN Cempaka Baru 07 Pagi. Dari hasil observasi dan analisis data diperoleh kesimpulan bahwa masalah yang timbul dalam pembelajaran IPS di kelas V SDN Cempaka Baru 07 Pagi dipengaruhi oleh beberapa faktor. Berdasar hasil wawancara dengan guru kelas V SDN Cempaka Baru 07 Pagi diperoleh informasi bahwa adanya beberapa siswa yang tidak terlalu aktif khususnya dalam hal bertanya. Hal ini disebabkan karena siswa kurang percaya diri untuk berbicara dan kurang mengerti terhadap materi pembelajaran yang sudah diajarkan, sehingga pembelajaran menjadi pasif. Selain itu, pada saat proses pembelajaran di kelas guru cenderung masih menggunakan model pembelajaran konvensional, sehingga berpengaruh pada keaktifan dalam belajar. Berdasar hasil wawancara dengan para siswa, siswa merasa kesulitan belajar IPS karena terlalu banyaknya materi yang perlu dihafal dan materinya berisi informasi yang jauh dari pengalaman mereka dan sulit untuk dipahami. Sebagian besar siswa menganggap mata pelajaran IPS tidak begitu penting karena tidak masuk pada mata pelajaran yang diujikan di Ujian Nasional. Selain itu, nampak juga dengan sikap siswa yang pasif, kurang berpartisipasi dalam diskusi dan pembelajaran. Beberapa siswa kurang menyimak materi dengan baik dan ketika pendidik memberi kesempatan kepada peserta didik untuk bertanya, tidak ada siswa yang bertanya,sehingga menjadi kesulitan ketika mengerjakan 
soal. Akibat kurangnya perhatian dan minat belajar peserta didik pada mata pelajaran IPS berdampak juga pada hasil belajar yang mereka capai.

Hal ini didukung analisis nilai evaluasi pada tanggal 1 Maret 2019 pada pembelajaran IPS Tema 7 Subtema 2 Peristiwa Kebangsaan Seputar Proklamasi di kelas V SDN Cempaka Baru 07 Pagi yang menunjukkan belum tercapainya kriteria ketuntasan minimal (KKM) yang telah ditetapkan sekolah, yaitu 70. Nilai rata-rata kelas yang diperoleh adalah sebesar 48,06 di mana 26 dari 31 siswa atau $83,87 \%$ mendapat nilai di bawah KKM yang ditentukan sekolah. Hal ini berarti bahwa kurang lebih 83,87 \% siswa masih belum dapat mencapai nilai KKM, yang mengindikasikan bahwa sebagian besar siswa kelas V SDN Cempaka Baru 07 Pagi belum dapat memahami dan menguasai materi dalam pembelajaran IPS.

Berdasarkan latar belakang masalah tersebut, ada dua faktor yang mempengaruhi masalah dalam pembelajaran IPS yaitu: (1) faktor internal dan (2) faktor eksternal. Faktor internal adalah faktor yang berasal dari dalam diri siswa sehingga mempengaruhi hasil belajar (Susanto, 2013: 12). Faktor internal meliputi: kecerdasan, minat dan perhatian, motivasi belajar, ketekunan, sikap, kebiasaan belajar, kondisi fisik, dan kesehatan. Beberapa faktor internal yang menjadi permasalahan dalam pembelajaran IPS di antaranya yaitu: (1) Kurangnya motivasi terhadap pembelajaran IPS; (2) Siswa merasa jenuh dan bosan dengan pembelajaran konvensional; serta (3) Kurangnya pemahaman siswa mengenai materi pembelajaran IPS.

Faktor eksternal adalah faktor yang berasal dari luar diri siswa sehingga mempengaruhi hasil belajar (Susanto, 2013: 12). Faktor eksternal meliputi: keluarga, sekolah, dan masyarakat. Wasliman (2007) dalam Susanto (2013:13) menyebutkan sekolah sebagai salah satu yang menentukan hasil belajar siswa. Semakin tinggi kualitas pengajaran dan kemampuan belajar siswa, semakin tinggi pula hasil belajar yang diperoleh siswa. Kualitas pengajaran di sekolah sangat ditentukan oleh peran seorang guru. Beberapa permasalahan yang terjadi dalam pembelajaran, khususnya IPS yaitu: (1) Guru lebih sering menggunakan model pembelajaran konvensional; (2) Kurangnya penguatan pembelajaran dari guru; serta (3) Kurang melibatkan partisipasi siswa sehingga pembelajaran menjadi kurang bermakna.

Fokus masalah pada penelitian ini adalah siswa kelas V di SDN Cempaka Baru 07 Pagi Jakarta Pusat. Dimana metode Everyone is Teacher Here ini akan diterapkan untuk meningkatkan hasil belajar siswa, khususnya tema 8 subtema 3 
jenis-jenis usaha dan kegiatan ekonomi masyarakat Indonesia. Rumusan masalah pada penelitian ini adalah (1) apakah penerapan metode Everyone is Teacher Here dapat meningkatkan hasil belajar IPS tema 8 subtema 3 pada siswa kelas V SD Negeri Cempaka Baru 07 Pagi Jakarta? Dan (2) seberapa besar penerapan metode Everyone is Teacher Here berpengaruh terhadap hasil belajar IPS tema 8 subtema 3 pada siswa kelas V SD Negeri Cempaka Baru 07 Pagi Jakarta?.

Tujuan umum penelitian ini yaitu untuk meningkatkan hasil belajar dengan menerapkan metode Everyone is Teacher Here. Adapun tujuan khusus penelitian ini merupakan penjabaran dari tujuan umum. Tujuan khusus dari penelitian ini yaitu meningkatkan hasil belajar IPS pada siswa kelas V SD Negeri Cempaka Baru 07 Pagi Jakarta dengan menerapkan metode Everyone is Teacher Here dan untuk mengetahui seberapa besar penerapan metode Everyone is Teacher Here berpengaruh terhadap hasil belajar IPS tema 8 subtema 3 pada siswa kelas V SD Negeri Cempaka Baru 07 Pagi Jakarta.

Belajar merupakan proses perubahan dalam kepribadian manusia sebagai hasil dari pengalaman atau interaksi antara individu dan lingkungan. Perubahan tingkah laku mencakup tiga ranah yaitu kognitif, afektif, dan psikomotor. Perubahan tingkah laku inilah yang menjadi tolok ukur keberhasilan proses belajar yang dialami peserta didik. Seorang guru harus berlandaskan pada prinsip-prinsip belajar yang berperan sebagai acuan untuk menentukan prosedurprosedur dalam kegiatan pembelajaran. Dimyati dan Mudjiono (2013: 42-9) merumuskan prinsip-prinsip belajar sebagai berikut: (1) perhatian dan motivasi, (2) keaktifan, (3) keterlibatan langsung, (4) pengulangan, (5) tantangan, (6) balikan dan penguatan, serta (7) perbedaan individual.

Rifa'i dan Anni (2009:193) menyatakan proses pembelajaran merupakan proses komunikasi antara pendidik dengan siswa atau antarsiswa, baik secara verbal (lisan) maupun nonverbal. Komunikasi ini ditujukan untuk membantu proses pembelajaran. Susanto (2016: 5) menyatakan hasil belajar adalah perubahan-perubahan yang terjadi pada diri siswa, baik yang menyangkut aspek kognitif, afektif, dan psikomotor sebagai hasil dari kegiatan belajar. Sesuai dengan pendapat tersebut, Rifa'i dan Anni (2009: 85) menyatakan hasil belajar adalah perilaku yang diperoleh siswa setelah mengalami kegiatan belajar. Aspek-aspek perubahan perilaku yang diperoleh oleh siswa bergantung pada apa yang dipelajari. Perubahan perilaku yang harus dicapai oleh siswa dirumuskan dalam tujuan pembelajaran. Dimyati dan Mudjiono (2013: 3) 
Dwi Rahmah Inayati, Ati Kusmawati : Penerapan Metode Everyone Is Teacher Here untuk Meningkatkan Hasil Belajar IPS Pada Siswa Kelas V SD Negeri Cempaka Baru 07 Pagi Jakarta

merumuskan hasil belajar sebagai hasil dari suatu interaksi tindak belajar dan mengajar.

Anak pada usia sekolah dasar termasuk dalam usia dini. Usia dini merupakan masa yang sangat penting bagi perkembangan seseorang. Oleh karena itu, guru harus mendorong kemampuan siswa agar berkembang secara optimal. Menurut Kurnia dkk. (2008: 4), siswa merupakan subjek utama dalam kegiatan pembelajaran, sehingga guru harus mampu memahami karakteristik siswa-siswanya. Hal tersebut bertujuan agar semua hal yang dibutuhkan siswa dapat diakomodasi oleh guru selaku pembimbing dalam belajar. Guru perlu memperhatikan tahap perkembangan kognitif yang dialami oleh siswa agar dapat memahami karakteristik siswa. Metode dalam serangkaian proses pembelajaran memegang peranan penting. Keberhasilan implementasi strategi pembelajaran sangat tergantung pada cara guru menggunakan metode pembelajaran, karena strategi pembelajaran hanya dapat diimplementasikan melalui penggunaan metode pembelajaran.

Dalam pembelajaran di kelas, banyak dijumpai diskusi yang tidak berjalan efektif karena didominasi oleh salah seorang peserta didik yang telah mempunyai skemata tentang apa yang akan dipelajarinya. Padahal selain membutuhkan skemata atau pengetahuan awal tentang apa yang akan dipelajari, peserta didik juga harus mempunyai keterampilan bertanya jawab. Metode Everyone is Teacher Here merupakan cara yang tepat untuk mendapatkan partisipasi kelas secara keseluruhan maupun individual. Metode ini memberikan kesempatan kepada semua siswa untuk berperan sebagi guru bagi kawankawannya sehingga terbentuk aktivitas belajar yang partisipatif dan aktif (Suprijono, 2017:110). Langkah-langkah metode pembelajaran Everyone is Teacher Here yaitu: (1) Guru membagikan kartu indeks kepada setiap siswa, lalu siswa membuat sebuah pertanyaan; (2) Guru mengumpulkan kartu lalu mengacak kartu secara adil dan memberikan kartu kembali kepada setiap siswa; (3) Siswa mencari jawaban pertanyaan dalam kartu indeks yang diterimanya.

Metode Everyone is Teacher Here telah banyak digunakan oleh penelitipeneliti sebelumnya. Dari beberapa hasil penelitian tersebut peneliti menganalisis beberapa kelebihan dan kelemahan pada penelitian-penelitian sebelumnya dengan maksud dapat dijadikan acuan dalam penelitian kali ini. Herningtyas (2013) dalam penelitiannya, Implementasi Metode Everyone Is A Teacher Here Berbantuan Media Kliping dalam Meningkatkan Kualitas Pembelajaran PKn 
pada Siswa Kelas V SDN Tugurejo 01, menghasilkan kesimpulan metode Everyone Is A Teacher Here dapat meningkatkan hasil belajar siswa pada mata pelajaran PKn. Hasil penelitian menunjukkan data sebagai berikut: (1) Aktivitas siswa pada siklus I memperoleh rata-rata skor 42,36 kategori baik, siklus II meningkat menjadi 49,96 kategori sangat baik; (2) Ketuntasan belajar siswa siklus I yaitu 59\%, kemudian siklus II ketuntasan meningkat menjadi 82,3\%. Nilai rata-rata kelas mencapai 77, 42.

Kelebihan pada penelitian tersebut adalah selain menggunakan metode Everyone is Teacher Here, penelitian ini juga menggunakan media kliping sehingga hasil yang didapatpun lebih baik. Hal yang diukur tidak hanya hasil belajar, tetapi juga aktivitas belajar. Peneliti melampirkan secara lengkap lembar pengamatan ketrampilan, lembar pengamatan aktivitas, hasil wawancara, hasil belajar tiap siklus, catatan lapangan, dan dokumentasi. Penelitian ini memiliki kekurangan yaitu hanya dilakukan dalam dua siklus dan tanpa melakukan pra siklus.

Persamaan penelitian ini dengan penelitian yang dilakukan oleh Herningtyas, yaitu dalam menerapkan metode Everyone is Teacher Here, jenis penelitian, dan kelas yang diteliti. Perbedaan antara penelitian yang dilakukan peneliti dengan Herningtyas yaitu pada mata pelajaran dan variabel yang diteliti. Peneliti menggunakan mapel IPS dan variabel hasil belajar, sementara Herningtyas menggunakan mapel IPA dan variabel kualitas pembelajaran. Peneliti mempunyai kelebihan yaitu menggunakan pra siklus dan berbantuan media mind map .

\section{METODE PENELITIAN}

Penelitian ini dilaksanakan di SD Negeri Cempaka Baru 07 Pagi Jakarta. Penerapan metode Everyone is Teacher Here dikatakan berhasil meningkatkan kualitas pembelajaran IPS di kelas V SD Negeri Cempaka Baru 07 Pagi jika dapat mencapai kriteria keberhasilan yang ditentukan. Kriteria keberhasilan dalam penelitian ini adalah hasil belajar siswa. Keberhasilan hasil belajar siswa dalam proses pembelajaran dapat diperoleh jika: (1) Nilai siswa pada ranah kognitif di atas KKM yaitu $\geq 70$; (2) Nilai siswa pada ranah afektif $\geq 2,33$; (3) Nilai siswa pada ranah keterampilan $\geq B$; (4) Rata-rata kelas $\geq 70$, (5) persentase tuntas belajar klasikal $\geq 70 \%$; dan (6) Hasil belajar siswa pada siklus II meningkat dari siklus I. Metode yang digunakan adalah penelitian tindakan 
Dwi Rahmah Inayati, Ati Kusmawati : Penerapan Metode Everyone Is Teacher Here untuk Meningkatkan Hasil Belajar IPS Pada Siswa Kelas V SD Negeri Cempaka Baru 07 Pagi Jakarta

kelas yang dilakukan dalam dua siklus, setiap siklus terdiri dari dua kali pertemuan. Sebelum memulai siklus I dilakukan pra siklus terlebih dahulu.

\section{HASIL DAN PEMBAHASAN}

Penelitian ini dikatakan berhasil jika ada peningkatan hasil belajar setelah menggunakan metode Everyone is Teacher Here dalam pembelajaran IPS tema 8 subtema 3 pembelajaran 3 dan 4 kelas V. Pada pra siklus peneliti menggunakan metode konvensional. Hasil belajar menunjukkan nilai evaluasi siswa secara rata-rata adalah 47,42. Dalam pra siklus tidak ada seorangpun yang mendapatkan nilai sempurna (100). Terdapat 6 siswa (19,35\%) siswa yang mampu mendapat nilai di atas KKM yang ditetapkan yaitu 70 .

Pada siklus I pertemuan 1 peneliti menggunakan metode Everyone is Teacher Here. Hasil belajar siswapun mengalami peningkatan. Terdapat 8 siswa atau sekitar $25.81 \%$ yang mampu mencapai nilai di atas KKM dengan hasil belajar rata-rata 49,36. Artinya masih terdapat 23 siswa yang belum mampu mencapai KKM. Pada siklus I pertemuan 1 dilakukan juga penilaian hasil belajar afektif dimana hasilnya mendapat rata-rata 3,27 kategori $\mathrm{B}+$, yang berarti nilai hasil belajar afektif sudah mencapai indikator keberhasilan nilai belajar.

Pada siklus I pertemuan 2 peneliti menggunakan metode Everyone is Teacher here dibantu media mind map. Disini siswa belum memakai mind map, hanya peneliti saja. Siswa baru diajarkan cara membuatnya dan waktu untuk mengerjakan mind map di sekolah tidak cukup sehingga dijadikan PR. Hasil belajar mengalami peningkatan signifikan. Terdapat 16 siswa atau 51,61\% yang mencapai nilai KKM dengan hasil belajar rata-rata 56,77. Terdapat 15 siswa atau 48,39 \% yang belum mencapai KKM. Pada siklus I pertemuan 2 ini juga dilakukan penilaian hasil belajar ranah keterampilan dimana hasilnya siswa yang mendapat nilai kategori A (sangat terampil) berjumlah 4 siswa (13\%), kategori B (terampil) 1 siswa (3\%), dan kategori C (cukup terampil) 26 siswa (84\%), yang menunjukkan bahwa hasil belajar keterampilan belum mencapai indikator keberhasilan yaitu rata-rata kategori B.

Pada siklus II pertemuan 1 peneliti menggunakan metode Everyone is Teacher Here berbantuan media mind map. Disini siswa sudah mempunyai mind map buatan masing-masing. Peneliti juga memberikan reward kepada siswa yang maju menjadi guru. Hal-hal tersebut menyebabkan hasil belajar 
siklus II pertemuan 1 meningkat secara signifikan. Di siklus ini ada siswa yang mendapat nilai sempurna (100). Terdapat 24 siswa $(77,42 \%)$ yang mencapai nilai KKM dengan nilai rata-rata 68,55 . Hal ini berarti ada 7 siswa yang belum mencapai nilai KKM. Nilai rata-rata belum mencapai indikator keberhasilan tetapi persentase ketuntasan klasikal belajar sudah melampaui indikator keberhasilan. Hasil belajar ranah afektif pada siklus II pertemuan 1 juga mengalami peningkatan, dimana nilai rata-rata adalah 3,52 dengan kategori Adan sudah mencapai indikator keberhasilan.

Pada siklus II pertemuan 2 peneliti menggunakan metode Everyone is Teacher Here dengan media mind map. Siswa maju menjadi guru menjawab pertanyaan dalam kartu indeks dan mempresentasikan mind map milik mereka. Selain itu juga digunakan reward untuk meningkatkan keterampilan siswa. Hasil belajar siswa ranah kognitif di pertemuan ini juga mengalami peningkatan, terdapat 25 siswa $(80,65 \%)$ yang sudah mencapai KKM dengan nilai rata-rata 74,19. Hal ini menunjukkan nilai rata-rata sudah mencapai KKM, persentase ketuntasan belajar klasikal sudah melebihi 70\%. Masih terdapat siswa yang belum mencapai KKM yaitu sebanyak 6 siswa. Hasil belajar ranah keterampilan pada siklus II pertemuan 2 juga mengalami peningkatan yaitu sebanyak $87 \%$ mendapat nilai terampil atau kategori B dan $13 \%$ mendapat nilai sangat terampil atau kategori A. Hal ini menunjukkan hasil belajar ranah keterampilan sudah mencapai indikator keberhasilan yaitu B.

Setelah dilakukannya kegiatan mulai dari prasiklus, siklus I dan siklus II, maka dapat diperoleh data peningkatan hasil belajar siswa dengan menggunakan metode Everyone is Teacher Here. Hal ini dapat dilihat dari nilai siswa dalam pembelajaran IPS pada tema 8 subtema 3 pembelajaran 3 dan 4 jenisjenis usaha dan kegiatan ekonomi masyarakat Indonesia. Penelitian menggunakan metode Everyone is Teacher Here mengalami peningkatan hasil belajar yang baik di setiap siklusnya.

Hasil belajar ranah kognitif diperoleh dari tes evaluasi di setiap akhir pertemuan di setiap siklus, sehingga ada lima tes evaluasi yang dilakukan. Hasil belajar siswa ranah kognitif di setiap siklusnya dapat dilihat dalam tabel 1 . 
Dwi Rahmah Inayati, Ati Kusmawati : Penerapan Metode Everyone Is Teacher Here untuk Meningkatkan Hasil Belajar IPS Pada Siswa Kelas V SD Negeri Cempaka Baru 07 Pagi Jakarta

Tabel 1. Hasil Belajar Ranah Kognitif Siswa

\begin{tabular}{|c|c|c|c|c|c|c|}
\hline \multirow[b]{2}{*}{ No } & \multirow[b]{2}{*}{ Pencapaian } & \multirow[b]{2}{*}{$\begin{array}{c}\text { Pra } \\
\text { Siklus }\end{array}$} & \multicolumn{2}{|c|}{ Siklus I } & \multicolumn{2}{|c|}{ Siklus II } \\
\hline & & & $\begin{array}{c}\text { Pertemuan } \\
\text { I }\end{array}$ & $\begin{array}{c}\text { Pertemuan } \\
\text { II }\end{array}$ & $\begin{array}{c}\text { Pertemuan } \\
\text { I }\end{array}$ & $\begin{array}{c}\text { Pertemuan } \\
\text { II }\end{array}$ \\
\hline 1. & $\begin{array}{l}\text { Nilai } \\
\text { Terendah }\end{array}$ & 10 & 10 & 15 & 25 & 45 \\
\hline 2. & $\begin{array}{l}\text { Nilai } \\
\text { Tertinggi }\end{array}$ & 95 & 90 & 95 & 100 & 100 \\
\hline 3. & $\begin{array}{l}\text { Siswa yang } \\
\text { Tuntas }\end{array}$ & 6 & 8 & 16 & 24 & 25 \\
\hline 4. & $\begin{array}{l}\text { Siswa yang } \\
\text { Belum } \\
\text { Tuntas }\end{array}$ & 25 & 23 & 15 & 7 & 6 \\
\hline 5. & $\begin{array}{l}\text { Nilai Rata- } \\
\text { Rata }\end{array}$ & 47.42 & 49.36 & 56.77 & 68.55 & 74.19 \\
\hline 6. & $\begin{array}{l}\text { Persentase } \\
\text { Ketuntasan } \\
\text { Belajar }\end{array}$ & 19.35 & 25.81 & 51.61 & 77.42 & 80.65 \\
\hline
\end{tabular}

Berdasarkan tabel 1, terjadi peningkatan nilai rata-rata di setiap siklus. Nilai rata-rata siswa dari 47,42 pada pra siklus meningkat menjadi 49,36 pada pertemuan 1. Nilai rata-rata meningkat menjadi 56,77 pada pertemuan 2. Kemudian pada siklus II pertemuan 1 meningkat lagi menjadi 68,55 dan pertemuan 2 menjadi 74,19. Jumlah siswa yang belum tuntas belajar atau mendapat nilai $<70$ pada pra siklus sebanyak 25 siswa, siklus I pertemuan 1 sebanyak 23 siswa, pertemuan 2 sebanyak 15 siswa. Siklus 2 pertemuan 1 berkurang kembali menjadi 7 siswa, setelah diadakan siklus II pertemuan 2 berkurang menjadi 6 siswa menjadikan 25 siswa tuntas belajar dengan presentase 80,65\%. Jadi dapat disimpulkan bahwa hasil belajar siswa meningkat dengan ketuntasan klasikal sebesar 80,65\%. Hasil ini sudah mencapai indikator keberhasilan yang ditentukan, yaitu ketuntasan klasikal sebanyak $70 \%$.

Penilaian tidak hanya dilakukan pada ranah belajar kognitif, akan tetapi juga dilakukan pada ranah afektif. Sikap yang dinilai dalam penelitian ini yaitu sikap siswa terhadap materi. Penilaian terhadap hasil belajar ranah afektif dilakukan pada siklus I dan siklus II. Hasil belajar ranah afektif dinilai menggunakan angket skala Likert. Pada angket skala Likert, skor maksimal 
yaitu 16 dan skor minimalnya 4. Jumlah pernyataan yang harus dijawab dalam angket tersebut yaitu 4 buah pernyataan, yang terdiri dari 2 pernyataan positif dan 2 pernyataan negatif. Cara pengisiannya, siswa hanya disuruh untuk mengisi angket dengan jawaban Sangat Setuju (SS), Setuju (S), Tidak Setuju (TS), dan Sangat Tidak Setuju (STS). KKM yang harus dicapai pada penilaian ini yaitu 2,33 dengan kategori B-. Hasil rekapitulasi penilaian sikap pada siklus I dan II dapat dilihat pada Tabel 2 .

Tabel 2. Hasil Belajar Ranah Afektif

\begin{tabular}{|c|l|c|c|}
\hline No & \multicolumn{1}{|c|}{ Pencapaian } & Siklus I & Siklus II \\
\hline 1. & Nilai Rata-rata & 3.27 & 3.52 \\
\hline 2. & Kategori & B+ & A- \\
\hline
\end{tabular}

Berdasarkan tabel 2 terjadi peningkatan nilai rata-rata di setiap siklus. Nilai rata-rata siswa dari 3,27 pada siklus I meningkat menjadi 3,52 pada siklus II. Semua siswa berhasil mencapai kategori minimal yang ditetapkan yaitu minimal B-. Berdasarkan hasil tersebut, dapat dinyatakan hasil belajar ranah afektif mengalami peningkatan dan telah memenuhi indikator keberhasilan yang ditetapkan.

Penilaian terhadap hasil belajar ranah keterampilan dilakukan pada siklus I dan siklus II. Data mentah yang diperoleh dari hasil tes psikomotorik kemudian diolah melalui cara penskoran dengan menilai setiap siswa, menghitung nilai rata-rata kemampuan siswa untuk mengetahui gambaran yang jelas mengenai hasil belajar siswa dalam pembelajaran Tema 8 (Lingkungan Sahabat Kita) Subtema 3 (Usaha Pelestarian Lingkungan). Hasil rekapitulasi penilaian keterampilan pada siklus I dan II dapat dilihat pada 3.

Tabel 3. Hasil Belajar Ranah Keterampilan

\begin{tabular}{|c|c|c|c|c|}
\hline $\begin{array}{c}\text { Nilai Rata- } \\
\text { rata }\end{array}$ & Kategori & Kualifikasi & \multicolumn{2}{|c|}{ Persentase } \\
\cline { 3 - 4 } & & & Siklus I & Siklus II \\
\hline $81-100$ & $\mathrm{~A}$ & Sangat Terampil & 13 & 13 \\
\hline $61-80$ & $\mathrm{~B}$ & Terampil & 3 & 87 \\
\hline $41-60$ & $\mathrm{C}$ & Cukup Terampil & 84 & 0 \\
\hline $20-40$ & $\mathrm{D}$ & Kurang Terampil & 0 & 0 \\
\hline
\end{tabular}


Berdasarkan tabel 3 terjadi peningkatan nilai rata-rata di setiap siklus. Nilai rata-rata siswa kategori C pada siklus I meningkat menjadi kategori B pada siklus II. Semua siswa berhasil mencapai kategori minimal yang ditetapkan yaitu minimal B. Berdasarkan hasil tersebut, dapat dinyatakan hasil belajar ranah keterampilan mengalami peningkatan dan telah memenuhi indikator keberhasilan yang ditetapkan.

Berdasarkan hasil penelitian tersebut maka dapat diinterpretasikan bahwa penelitian ini menunjukkan penerapan metode Everyone is Teacher Here efektif digunakan untuk meningkatkan hasil belajar IPS kelas V tema 8 subtema 3 pembelajaran 3 dan 4 .

\section{PENUTUP}

Berdasarkan analisis data dan pembahasan, menunjukkan bahwa penerapan metode Everyone is Teacher Here dapat meningkatkan hasil belajar siswa pada pelajaran IPS tema 8 subtema 3 materi jenis usaha dan kegiatan ekonomi masyarakat Indonesia di kelas V SD Negeri Cempaka Baru 07 Pagi. Hasil penelitian menunjukkan nilai rata-rata siswa dari 47,42 pada pra siklus meningkat menjadi 49,36 pada pertemuan 1, meningkat menjadi 56,77 pada pertemuan 2. Pada siklus II pertemuan 1 meningkat lagi menjadi 68,55 dan pertemuan 2 menjadi 74,19. Persentase tuntas belajar pra siklus 19,35\% meningkat di siklus I pertemuan 1 menjadi $25,81 \%$, pertemuan 2 menjadi $51,61 \%$, siklus II pertemuan 1 menjadi $77,42 \%$ dan pertemuan 2 menjadi $80,65 \%$. Perolehan nilai rata-rata hasil belajar afektif pada siklus I sebesar 3,27 (B+), kemudian meningkat pada siklus II menjadi 3,52 (A). Hasil belajar ranah keterampilan siklus I mendapat nilai rata-rata kategori $\mathrm{C}$ dan meningkat di siklus II menjadi kategori B.

Dari hasil penelitian disimpulkan bahwa metode Everyone is Teacher Here dapat meningkatkan hasil belajar IPS pada siswa kelas V SDN Cempaka Baru 07 Pagi dan disarankan metode Everyone is Teacher Here diterapkan juga pada mata pelajaran lain. Diharapkan guru dapat merancang kegiatan pembelajaran menggunakan metode Everyone is Teacher Here pada materi yang bersifat teori. Metode Everyone is Teacher Here merupakan metode yang dapat meningkatkan rasa percaya diri siswa, menarik, dan menyenangkan. Pembelajaran yang menarik dan menyenangkan meningkatkan rasa kenyamanan siswa sehingga pembelajaran menjadi lebih bermakna. 


\section{DAFTAR PUSTAKA}

Dimyati dan Mudjiono. 2013. Belajar dan Pembelajaran. Jakarta: Rineka Cipta. Herningtyas, Diani. 2013. Implementasi Metode Everyone is A Teacher Here Berbantuan Media Kliping Dalam Meningkatkan Kualitas Pembelajaran PKn pada Siswa Kelas V SDN Tugurejo 01. Skripsi. Universitas Negeri Semarang.

Kurnia, Ingridwati, dkk. 2008. Perkembangan Belajar Peserta Didik. Jakarta: Departemen Pendidikan Nasional

Rifa'i, Achmad dan C. T. Anni. 2009. Psikologi Pendidikan. Semarang: UNNES PRESS.

Suprijono, Agus. 2017. Cooperative Learning Teori dan Aplikasi PAIKEM. Yogyakarta : Pustaka Pelajar.

Susanto, Ahmad. 2016. Teori Belajar dan Pembelajaran di Sekolah Dasar. Jakarta: Kencana Prenada Media Group. 